\title{
IMPROVING STUDENTS' WRITING SKILLS OF RECOUNT TEXT BY APPLYING TRANSITION-ACTION-DETAILS (TAD) STRATEGY
}

\author{
Muh. Arief Muhsin \\ Muhammadiyah University of Makassar, Indonesia \\ (arief.m@unismuh.ac.id)
}

Received: $14^{\text {th }}$ October 2017; Revised: $21^{\text {th }}$ November 2017; Accepted: $28^{\text {th }}$ December 2017

\begin{abstract}
This research aimed to explain how the use of the Transition-Action-Details (TAD, hereafter) Strategy improved students' skills in writing Recount Text dealing with the content of writing. It also aimed to explain how the TAD Strategy improved students' skills in writing Recount Text dealing with the organization of writing. Employing CAR as the reseaech design, the research findings indicate that TAD Strategy improves students' writing skills of Recount Text. It was proven by the writing Recount Text of the students' mean score in cycle 2 test result (78.95). This improved from the cycle 1 mean score (68.95). It improved significantly from diagnostic test (D - test) mean score (61.04). The writing Recount Text of the students' achievement in cycle 2 indicated that it had met the score target (70.00), and considered to be successful criteria in improving the writing Recount Text through TAD Strategy. Based on the findings above, the author concluded that using TAD Strategy could improve the writing Recount Text of the students.
\end{abstract}

Key Words: writing; recount text; transition-action-details

\begin{abstract}
ABSTRAK
Penelitian ini bertujuan untuk menjelaskan bagaimana penggunaan Strategi Transisi-Aksi-Detail (TAD, selanjutnya) Strategi meningkatkan keterampilan siswa dalam menulis Recount Text yang berhubungan dengan isi tulisan. Ini juga bertujuan untuk menjelaskan bagaimana Strategi TAD meningkatkan keterampilan siswa dalam menulis Recount Text yang berhubungan dengan organisasi penulisan. Temuan penelitian menunjukkan bahwa TAD Strategy meningkatkan keterampilan menulis siswa dari Recount Text. Hal ini terbukti dengan penulisan Recount Text dari nilai rata-rata siswa dalam hasil tes siklus $2(78,95)$. Ini meningkat dari skor rata-rata siklus $1(68,95)$. Ini meningkat secara signifikan dari tes diagnostik (D-test) skor rata-rata $(61,04)$. Tulisan Recount Text tentang pencapaian siswa dalam siklus 2 menunjukkan bahwa mereka telah memenuhi target skor (70,00), dan dianggap sebagai kriteria yang berhasil dalam meningkatkan penulisan Recount Text melalui TAD Strategy. Berdasarkan temuan di atas, penulis menyimpulkan bahwa menggunakan TAD Strategy dapat meningkatkan penulisan Recount Text dari para siswa.
\end{abstract}

Kata Kunci: writing; recount text; transition-action-details

How to Cite: Muhsin, M. A. (2017). Improving Students' Writing Skills of Recount Text by Applying TransitionAction-Details (TAD) Strategy. IJEE (Indonesian Journal of English Education), 4(2), 156-167. doi:10.15408/ijee.v4i2.2430 


\section{INTRODUCTION}

In writing, we need a good idea in order to produce a composition or written material (Syamsuri, Muhsin \& Nurmayani, 2016). If students do not have ideas, they will get bored and disinterested in writing. For writing subject, students must have ideas about what they will write and how far they know about the topic (Patel \& Jain, 2008); sometimes they have to choose one theme and then decide on one topic, finding the appropriate word to express an idea (Anderson \& Anderson, 1997).

As any writing teacher has experienced, students are frequently worried about the prospect of writing in English (Gerlach, 1994). They worry about paragraph writing almost as much as about longer research papers in English (Patel, 2008). They worry about expressing their ideas clearly within the boundaries of correct usage, grammar, spelling, and punctuation (Byrne, 1986). Often in the initial years of their language learning, there is little focus on the creative aspects of writing because exams generally focus more on grammar, spelling, or punctuation. Because of this, students develop a fear of writing and think that everything they write is riddled with errors (Derewianka, 2004). These fears hinder them and frequently make their writing process slow and also unsuccessful (Paltridge, 2004).

Considering the above mentioned, the present study aimed at finding a good solution and making the students interested in writing English (Helnich \& Farhady, 1982; Morley, 2007), and changes the opinion that says: the students consider writing as the hardest skill to acquire (Yakkop, 2006). There are ways to solve these problems, starting from providing various learning resources to be read in every semester (Mayers, 2002), applying various learning methods, and offering various kinds of learning aids (Allen, 1972).

As a response to the aim above, an observation of English teaching was conducted by using TAD Strategy. The reason for this application is based on the assumption that by using this strategy, Recount Textthe students' writing skills of Recount Text can be facilitated effectively (Oshima \& Hogue, 1997).

TAD Strategy shows a lot of words or ideas among the events on the story and keeps them loosely connected where the writer can draw picture to be displayed (Marpaung, 2012). The sequence of event is then described in some sort of order, for instance a time order. 
Regarding to the descriptions above, the author is interested in implementing TAD Strategy in improving students skills' in writing Recount Text. The author is interested in implementing this strategy due to the students' relatively low skills in English, especially in writing Recount Text.

TAD Strategy is one of the strategies in teaching writing Recount Text process. Below is its definition:

\section{- Transition}

A well-organized essay is the basic for coherence. Hence, there is a way that aids to coherence among the paragraph in order to the paragraph have logic easy to read and to understand. Christie and Maton in Tarigan, (2011) stated that transition is chain-link as a connector among paragraphs. It has the function as a connector nearby two idea paragraph. It means that it works as a support paragraph in order to achieve coherence. Furthermore, this is similar to Reid (2005) who stated that transition in English sometimes called connector which has different grammatical uses. Then, this is different from Peha (2003) that pointed out that transition is a short phrase like "Then" or "After a while" or "in the beginning" that helps introduce each new action in these sequences. It is not necessary to have a transition for each action. However, transition can help writing flow more smoothly from section to section.

Based on the statements above, it can be inferred that transition works as a signal relationship among the sentences of the paragraph. It has the function as support coherence among the sentence and leads the sentence which will be discussed. Thus, the transition in the sentences connects a topic to one another on the paragraph.

- Action

According to Peha (2003), action is actual events (the thing that happened) listed in the order in which they occurred. Thus, in this scene the writer needs the event to describe the action in order to know what going on. In conclusion, action is the process event which is being done by people based on their sequence of events to get the purpose. This is the character's people do and say that happen to them (Lin, 2006). 
- Details

Peha (2003) defined detail as additional information about each action. For each action, the audience will probably have transition action detail strategy two or three important questions needed to answer. These answers are details. In conclusion, detail is the way to support information an action in one paragraph or more in order to be completed (Muhsin, M. A., 2016). Detail is extremely important part of writing. Because without details it is hard for readers to know exactly what a writer is trying to say. It means that this TAD Strategy can be used for the students to write Recount Text by concerning the three basic structures such as transition, action, and detail. Furthermore, this strategy can also engage students' imagination or experience to write Recount Text easier.

TAD Writing Strategy pioneered by Peha (2003) is a writing strategy that uses TAD chart consisting of columns and rows showing a sequence of events. There are three columns that must be filled by participants, such as transitions columns, action columns, and details columns. Each column can be filled by several rows. After filling each row and column with sentences, students can move the sentences consisting of transitional signals, sequence of events, and some details actions into a new recount paragraph.

\section{METHODS \\ Research Design}

This research followed the principal working of Classroom Action Research (CAR, hereafter) that contained of four stages; they were planning, implementation of action, observation, and reflection (Donahue, 2003; Kusumah \& Dwitagama, 2011).

This research was held in two cycles. They were first and second cycle, and each cycle was the series of activity which had a close relation. The realization of the second cycle was continuing and re-correcting from the first cycle. Each cycle was conducted in four meetings.

\section{Research Subject}

The study was conducted at Madrasah Aliyah Negeri (MAN) Pangkep Regency for English subject. The subjects of this research were students of Class X.I in 2013-2014 academic years. 


\section{Research Instrument}

The research employed two instruments for collecting data:

\section{Test}

The test was used to measure the students' writing skills through Transition-Action-Details Strategy. It was done to know the improvement of writing skills of students. The test was given at the end of cycle one. Then, at the end of cycle two, a test was given again as the last evaluation test. From that last test, the author knew the improvement of students' writing skill.

2. Observation sheet

It was aimed to collect data about the students' participations in teaching learning process through TransitionAction-Details Strategy.

\section{Research Procedures}

In this study, the author used the CAR principle to collect the data. The research was divided into two cycles with each cycle consisted of four phases.

The cycle was described through the scheme of action research phases as follows Figure 1.

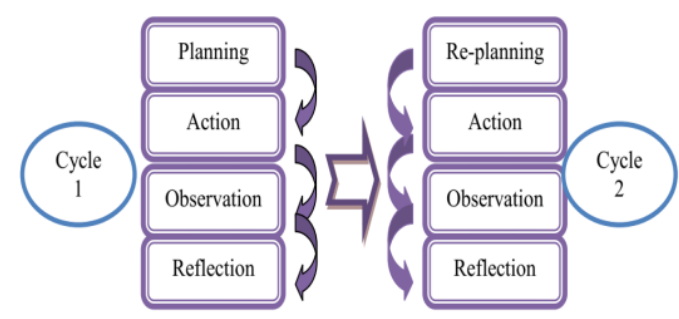

Figure 1. The Cycle of Classroom Action Research

\section{Technique of Data Analysis}

The data in the CAR from the score was analyzed using the following formula: a) To find out the mean score of the students' writing test through TAD Strategy, the author used the following formula:

$$
\bar{x}=\frac{\sum x}{N}
$$

$$
\begin{array}{ll}
\text { Note } & : \\
\bar{x} & =\text { Mean Score } \\
\sum x & =\text { Total Score } \\
\mathrm{N} & =\text { Number of Subject (Gay, 1981). }
\end{array}
$$

b) To calculate the percentage of the students' activity in learning process using formula:

$$
P=\frac{F}{N} X_{100 \%}
$$

Note:

$$
\begin{aligned}
& \text { P : Percentage } \\
& \text { F : : Frequency } \\
& \text { N : Total number of Subject (Hatch and Hassen }
\end{aligned}
$$

c) To know the students' participation in teaching learning process through 
TAD Strategy, the author used percentage formula as follows:

$$
\begin{aligned}
& P= F Q \times 100 \% \\
& 4 x N
\end{aligned}
$$

Where:

$\mathrm{P} \quad=$ Percentage

FQ = Sum of all the student's score

$\mathrm{N} \quad=$ Total students (Sudjana, 1990).

\section{FINDINGS AND DISCUSSION}

The improvement of the students' skill in writing Recount Text through TAD Strategy based on the result of the students' assessment is described as follow table 1 .

Table 1 shows the means score of the students' writing ability in D-test was 61.04. Then, in the first cycle showed that the means score of unity was 68.58 the mean score of completeness was 67.70 , the mean score of coherence was 68.12 , the mean score of spatial order was 67.50 , and the total of the mean score in the first cycle was 68.95. Meanwhile, in the second cycle, the mean score of unity was 77.91, the mean score of completeness was 77.70, the mean score of Coherence was 77.91, the mean score of spatial order was 77.70 , and the total of mean score in the second cycle was 78.95 .

The table 2 shows that, the students' mean score of diagnostic test before the implementation of TAD Strategy was 61.04 which was categorized as "Fairly good". After conducting the first cycle and the second cycles, the result showed that the students' scores in the first and second cycles improved. In the first cycle, the mean score of students was 68.95, classified as "Fairly good"; meanwhile, the mean score of students in the second cycle was 78.95 , classified as "Good".

\begin{tabular}{|c|c|c|c|c|c|c|}
\hline \multirow{3}{*}{$\mathrm{T}^{\text {D-test }} \mathrm{X}^{-1}$} & \multirow[t]{3}{*}{ Cycle } & \multicolumn{4}{|c|}{ Variables } & \multirow{3}{*}{$\begin{array}{l}\text { Mean } \\
\text { Score }\end{array}$} \\
\hline & & \multicolumn{2}{|c|}{ Content } & \multicolumn{2}{|c|}{ Organization } & \\
\hline & & Unity & Completeness & Coherence & $\begin{array}{c}\text { Spatial } \\
\text { Order }\end{array}$ & \\
\hline \multirow{2}{*}{$T^{61.04}$} & I & 68.58 & 67.70 & 68.12 & 67.50 & 68.95 \\
\hline & II & 77.91 & 77.70 & 77.91 & 77.70 & 78.95 \\
\hline
\end{tabular}

Table 1. The Mean Score of the Students' Skill in Writing Recount Text

Table 2. The Classification of the Students' Writing Skill

\begin{tabular}{lllll}
\hline No. & Cycle & Score & Mean Score & Classification \\
\hline $\mathbf{1}$ & D - Test & 1465 & 61.04 & Fairly good \\
$\mathbf{2}$ & Cycle 1 & 1655 & 68.95 & Fairly good \\
$\mathbf{3}$ & Cycle 2 & 1895 & 78.95 & Good \\
\hline
\end{tabular}


The data above can also be seen in the following diagram:

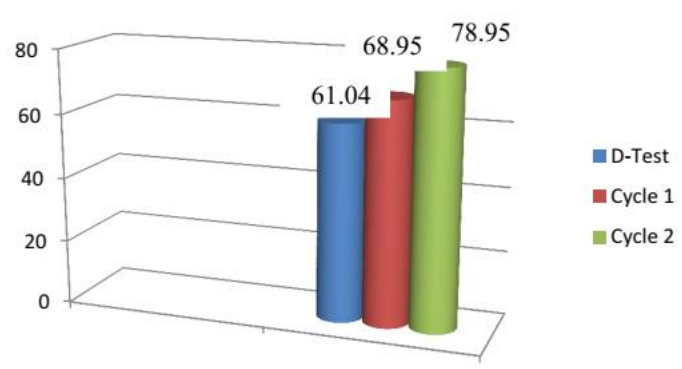

Graphic 1. The Classification of the Students' Writing Skill

This diagram shows that there was improvement in each cycle after the implementation of TAD Strategy. It was shown that the mean score in D-Test was 61.04 , the mean score in the first cycle was 68.95 , and the mean score in the second cycle was 78.95.

\section{Application of TAD Strategy in Variable of Content (Unity)}

Table 3. The Mean Score of the Students' Score in Indicator "Unity"

Mean Score of Indicator "Unity"

\begin{tabular}{llc}
\hline Non-TAD & \multicolumn{2}{l}{ The Application of TAD Strategy } \\
Strategy & & \\
D-Test & Cycle I & Cycle II \\
$\mathbf{6 0 . 2 0}$ & 68.54 & 77.91 \\
\hline
\end{tabular}

The table 3 shows that the mean score of the students' writing ability in variable of content (unity) in diagnostic test before using TAD Strategy was 60.20. After applying treatment in the first cycle, the mean score was 68.54, meanwhile in the second cycle, the mean score was 77.91.

Table 4 Rate Percentage of the Students'

Score in Indicator "Unity"

\begin{tabular}{|c|c|c|c|c|c|c|c|}
\hline \multirow[t]{3}{*}{$\begin{array}{l}\text { Classificat } \\
\text { ion }\end{array}$} & \multirow[t]{3}{*}{$\begin{array}{l}\text { Ran } \\
\text { ge }\end{array}$} & \multicolumn{2}{|c|}{ D-Test } & \multicolumn{4}{|c|}{$\begin{array}{l}\text { Application of } \\
\text { Transition-Action- } \\
\text { Details Strategy }\end{array}$} \\
\hline & & $\bar{F}$ & $\%$ & & le I & & le 2 \\
\hline & & & & F & $\%$ & $\mathrm{~F}$ & $\%$ \\
\hline Excellent & $\begin{array}{l}90- \\
100\end{array}$ & 0 & 0 & 0 & 0 & 0 & 0 \\
\hline Very good & $\begin{array}{l}80- \\
89\end{array}$ & 0 & 0 & 1 & $4 \%$ & $\begin{array}{l}1 \\
5\end{array}$ & $\begin{array}{l}62 \\
\%\end{array}$ \\
\hline Good & $\begin{array}{l}70 \\
79\end{array}$ & 4 & $\begin{array}{l}17 \\
\%\end{array}$ & $\begin{array}{l}1 \\
4\end{array}$ & $\begin{array}{l}58 \\
\%\end{array}$ & 9 & $\begin{array}{l}38 \\
\%\end{array}$ \\
\hline Fair good & & $\begin{array}{l}1 \\
5\end{array}$ & $\begin{array}{l}63 \\
\%\end{array}$ & 9 & $\begin{array}{l}38 \\
\%\end{array}$ & 0 & 0 \\
\hline Fair & $\begin{array}{l}50- \\
59\end{array}$ & 5 & $\begin{array}{l}20 \\
\%\end{array}$ & 0 & 0 & 0 & 0 \\
\hline Total & & $\begin{array}{l}2 \\
4\end{array}$ & $\begin{array}{l}100 \\
\%\end{array}$ & $\begin{array}{l}2 \\
4\end{array}$ & $\begin{array}{l}100 \\
\%\end{array}$ & $\begin{array}{l}2 \\
4\end{array}$ & $\begin{array}{l}100 \\
\%\end{array}$ \\
\hline
\end{tabular}

The table 4. shows that, the rate percentage of the students' writing ability in diagnostic test before applying TAD Strategy was 5 students (21\%) were classified as fair, 15 students $(62 \%)$ were classified as fairly good, 4 students $(17 \%)$ were classified as good from 24 respondents. After applying treatment, especially in variable of content (unity), the last evaluation showed that the first cycle were 9 students $(38 \%)$ were classified as fairly good, 14 students $(58 \%)$ were classified as good and 1 students (4\%) were classified very good from 24 respondents, meanwhile the second 
cycle were 9 students (38\%) were classified as good and 15 students (62\%) were classified as very good from 24 respondents.

2. Application of TAD Strategy in Variable of Content (Completeness)

Table 5. The Mean Score of the Students' Score in Indicator "Completeness"

\begin{tabular}{lll}
\hline \multicolumn{4}{l}{ Mean Score of Indicator "Completeness" } \\
\hline Non-TAD & The Application of TAD \\
Strategy & Strategy & \\
& & \\
D-TEST & Cycle I & Cycle II \\
$\mathbf{5 9 . 3 7}$ & 67.70 & 77.70 \\
\hline
\end{tabular}

Table 6. Rate Percentage of the Students' Score in Indicator "Completeness"

\begin{tabular}{|c|c|c|c|c|c|c|c|c|}
\hline \multirow[t]{3}{*}{$\begin{array}{l}\text { Classificat } \\
\text { ion }\end{array}$} & \multirow{3}{*}{\multicolumn{2}{|c|}{$\begin{array}{l}\text { Ran } \\
\text { ge }\end{array}$}} & \multicolumn{2}{|c|}{ D-Test } & \multicolumn{4}{|c|}{$\begin{array}{l}\text { Application of } \\
\text { Transition-Action- } \\
\text { Details Strategy }\end{array}$} \\
\hline & & & \multirow[t]{2}{*}{$\mathrm{F}$} & \multirow[t]{2}{*}{$\%$} & \multicolumn{2}{|c|}{ Cycle I } & \multicolumn{2}{|c|}{ Cycle 2} \\
\hline & & & & & $\mathrm{F}$ & $\%$ & $\mathrm{~F}$ & $\%$ \\
\hline Excellent & $\begin{array}{l}90 \\
100\end{array}$ & - & 0 & 0 & 0 & 0 & 1 & $4 \%$ \\
\hline Very good & $\begin{array}{l}80 \\
89\end{array}$ & - & 0 & 0 & 1 & $4 \%$ & $\begin{array}{l}1 \\
4\end{array}$ & $\begin{array}{l}58 \\
\%\end{array}$ \\
\hline Good & $\begin{array}{l}70 \\
79\end{array}$ & - & 4 & $\begin{array}{l}17 \\
\%\end{array}$ & $\begin{array}{l}1 \\
2\end{array}$ & $\begin{array}{l}50 \\
\%\end{array}$ & 9 & $\begin{array}{l}38 \\
\%\end{array}$ \\
\hline Fair good & $\begin{array}{l}60 \\
69\end{array}$ & - & $\begin{array}{l}1 \\
1\end{array}$ & $\begin{array}{l}46 \\
\%\end{array}$ & $\begin{array}{l}1 \\
1\end{array}$ & $\begin{array}{l}46 \\
\%\end{array}$ & 0 & 0 \\
\hline Fair & $\begin{array}{l}50 \\
59\end{array}$ & - & 9 & $\begin{array}{l}37 \\
\%\end{array}$ & 0 & 0 & 0 & 0 \\
\hline Total & & & $\begin{array}{l}2 \\
4\end{array}$ & $\begin{array}{l}100 \\
\%\end{array}$ & $\begin{array}{l}2 \\
4 \\
\end{array}$ & $\begin{array}{l}100 \\
\% \\
\end{array}$ & $\begin{array}{l}2 \\
4 \\
\end{array}$ & $\begin{array}{l}100 \\
\% \\
\end{array}$ \\
\hline
\end{tabular}

The table 5 shows that the mean score of the students' writing ability in variable of content (completeness) in diagnostic test before applying TAD
Strategy was 59.37. After applying treatment in the first cycle, the mean score was 67.70, meanwhile in the second cycle, the mean score was 77.70.

The table above shows that, the rate percentage of the students' writing ability in diagnostic test before using TAD Strategy was 9 students (37\%) were classified as fair, 11 students (63\%) were classified as fairly good and 4 students $(17 \%)$ were classified as good from 24 respondents. After applying treatment especially in variable of content (completeness), the last evaluation shows that in the first cycle, 11 students (46\%) were classified as very fairly good, 12 students (50\%) were classified as good and 1 students (4\%) were classified very good from 24 respondents, meanwhile in the second cycle, 9 students (38\%) were classified as good, 14 students (58\%) were classified as very good and 1 students (4\%) were classified excellent from 24 respondents.

\section{Application of TAD Strategy in Variable of Organization (Coherence)}

Table 7. The Mean Score of the Students' Score in Indicator "Coherence"

\begin{tabular}{llll}
\hline \multicolumn{4}{l}{ Mean Score of Indicator "Coherence" } \\
\hline Non-TAD & The Application & of & TAD \\
Strategy & Strategy & & \\
D-Test & Cycle I & Cycle II \\
60,41 & 68,12 & 77,91 & \\
\end{tabular}


Table 8. Rate Percentage of the students' score in indicator "Coherence"

\begin{tabular}{|c|c|c|c|c|c|c|c|}
\hline \multirow[t]{3}{*}{$\begin{array}{l}\text { Classific } \\
\text { ation }\end{array}$} & \multirow[t]{3}{*}{$\begin{array}{l}\text { Ran } \\
\text { ge }\end{array}$} & \multicolumn{2}{|c|}{ D-Test } & \multicolumn{4}{|c|}{$\begin{array}{l}\text { Application } \\
\text { TAD Strategy }\end{array}$} \\
\hline & & $\mathrm{F}$ & $\%$ & & le I & & le 2 \\
\hline & & & & $F$ & & $\mathrm{~F}$ & $\%$ \\
\hline Excellent & $\begin{array}{l}90- \\
100\end{array}$ & 0 & 0 & 0 & 0 & 0 & 0 \\
\hline $\begin{array}{l}\text { Very } \\
\text { good }\end{array}$ & $\begin{array}{l}80- \\
89\end{array}$ & 0 & 0 & 1 & $4 \%$ & $\begin{array}{l}1 \\
6\end{array}$ & $\begin{array}{l}67 \\
\%\end{array}$ \\
\hline Good & $\begin{array}{l}70- \\
79\end{array}$ & 3 & $\begin{array}{l}12 \\
\%\end{array}$ & 1 & $\begin{array}{l}54 \\
\%\end{array}$ & 8 & $\begin{array}{l}33 \\
\%\end{array}$ \\
\hline Fair good & $\begin{array}{l}60- \\
69\end{array}$ & $\begin{array}{l}1 \\
5\end{array}$ & $\begin{array}{l}63 \\
\%\end{array}$ & $\begin{array}{l}1 \\
0\end{array}$ & $\begin{array}{l}42 \\
\%\end{array}$ & 0 & 0 \\
\hline Fair & $\begin{array}{l}50- \\
59\end{array}$ & 6 & $\begin{array}{l}25 \\
\%\end{array}$ & 0 & 0 & 0 & 0 \\
\hline Total & & $\begin{array}{l}2 \\
4\end{array}$ & $\begin{array}{l}100 \\
\%\end{array}$ & $\begin{array}{l}2 \\
4\end{array}$ & $\begin{array}{l}100 \\
\%\end{array}$ & $\begin{array}{l}2 \\
4\end{array}$ & $\begin{array}{l}100 \\
\%\end{array}$ \\
\hline
\end{tabular}

The table 7 shows that the mean score of the students' writing ability in variable of organization (Coherence) in the diagnostic test before applying TAD Strategy was 60.41. After applying treatment in the first cycle, the mean score was 68.12, meanwhile in the second cycle, the mean score was 77.91.

The table 8 shows that, the rate percentage of the students' writing ability in diagnostic test before applying TAD Strategy was 6 students $(25 \%)$ who were classified as fair, 15 students $(63 \%)$ were classified as fairly good, and 3 students (12\%) were classified as good from 24 respondents. After applying treatment especially in variable of organization (Coherence), the last evaluation shows that in the first cycle, 10 students (42\%) were classified as fairly good, 13 students $(54 \%)$ were classified as good and 1 students (4\%) were classified as very good from 24 respondents, meanwhile in the second cycle, 8 students (33\%) were classified as very good and 16 students $(67 \%)$ were classified as very good from 24 respondents.

4. Application of TAD Strategy in Variable of Organization (Spatial order )

Table 9. The Mean Score of the Students' Score in Indicator "Spatial order"

\begin{tabular}{|c|c|c|}
\hline \multicolumn{3}{|c|}{ Mean Score of Indicator "Spatial order" } \\
\hline Non-TAD & The Ap & f TAD Strategy \\
\hline D-Test & Cycle I & Cycle II \\
\hline 60.20 & 67.05 & 77.70 \\
\hline
\end{tabular}

Table 10. Rate percentage of the Students Score in Indicator "Spatial order"

\begin{tabular}{|c|c|c|c|c|c|c|c|c|}
\hline \multirow[t]{2}{*}{$\begin{array}{l}\text { Classifica } \\
\text { tion }\end{array}$} & \multirow{2}{*}{\multicolumn{2}{|c|}{$\begin{array}{l}\text { Ran } \\
\text { ge }\end{array}$}} & \multicolumn{2}{|c|}{ D-Test } & \multicolumn{4}{|c|}{$\begin{array}{l}\text { Application } \\
\text { TAD Strategy }\end{array}$} \\
\hline & & & $\mathrm{F}$ & $\%$ & & le I & & le 2 \\
\hline Excellent & $\begin{array}{l}90 \\
100\end{array}$ & & 0 & 0 & $\begin{array}{l}\mathrm{F} \\
0\end{array}$ & $\begin{array}{l}\% \\
0\end{array}$ & $\begin{array}{l}\mathrm{F} \\
0\end{array}$ & $\begin{array}{l}\% \\
0\end{array}$ \\
\hline $\begin{array}{l}\text { Very } \\
\text { good }\end{array}$ & $\begin{array}{l}80 \\
89\end{array}$ & - & 0 & 0 & 1 & $4 \%$ & $\begin{array}{l}1 \\
4\end{array}$ & $\begin{array}{l}58 \\
\%\end{array}$ \\
\hline Good & $\begin{array}{l}70 \\
79\end{array}$ & - & 3 & $\begin{array}{l}12 \\
\%\end{array}$ & $\begin{array}{l}1 \\
1\end{array}$ & $\begin{array}{l}46 \\
\%\end{array}$ & $\begin{array}{l}1 \\
0\end{array}$ & $\begin{array}{l}42 \\
\%\end{array}$ \\
\hline Fair good & $\begin{array}{l}60 \\
69\end{array}$ & - & $\begin{array}{l}1 \\
4\end{array}$ & $\begin{array}{l}59 \\
\%\end{array}$ & $\begin{array}{l}1 \\
2\end{array}$ & $\begin{array}{l}50 \\
\%\end{array}$ & 0 & 0 \\
\hline Fair & $\begin{array}{l}50 \\
59\end{array}$ & - & 7 & $\begin{array}{l}29 \\
\%\end{array}$ & 0 & 0 & 0 & 0 \\
\hline Total & & & $\begin{array}{l}2 \\
4\end{array}$ & $\begin{array}{l}100 \\
\%\end{array}$ & $\begin{array}{l}2 \\
4\end{array}$ & $\begin{array}{l}100 \\
\%\end{array}$ & $\begin{array}{l}2 \\
4\end{array}$ & $\begin{array}{l}100 \\
\%\end{array}$ \\
\hline
\end{tabular}


The table 9 shows that the mean score of the students' writing ability in variable of organization (spatial order) in the diagnostic test before applying TAD Strategy was 60.20. After applying treatment in the first cycle, the mean score was 67.05, meanwhile in the second cycle, the mean score was 77.70.

The table 10. shows that, the rate percentage of the students' writing ability in diagnostic test before using TAD Strategy was 7 students (29\%) who were classified as fair, 14 students (59\%) were classified as fairly good, 3 students (12\%) from 24 respondents. After applying treatment especially in variable of organization (spatial order), the last evaluation shows that in the first cycle, 12 students (50\%) were classified as fairly good, 11 students $(46 \%)$ were classified as good and 1 students (4\%) were classified very good from 24 respondents, meanwhile in the second cycle, 10 students (42\%) were classified as good, 14 students (58\%) were classified as very good from 24 respondents.

\section{Observation Result}

The observation result of the students' participation in teaching and learning process is shown in the following table 11.
Table 11. The Percentage of the Students' Participation

\begin{tabular}{llllll}
\hline Cycl & \multicolumn{3}{l}{ Students' Participation } & & $\begin{array}{l}\text { Avera } \\
\text { e }\end{array}$ \\
\cline { 2 - 5 } & \multicolumn{2}{l}{ Meeting } \\
& $1^{\text {st }}$ & $2^{\text {nd }}$ & $3^{\text {rd }}$ & $4^{\text {th }}$ & Score \\
I & 40.62 & 47.91 & 53.12 & 60.41 & 50.51 \\
& $\%$ & $\%$ & $\%$ & $\%$ & \\
II & 69.79 & $75 \%$ & 85.41 & 88.54 & 79.68 \\
& $\%$ & & $\%$ & $\%$ & \\
\hline
\end{tabular}

The table above explained about average of the students' activeness in teaching and learning process in every meeting. The percentages of cycle I from the first meeting to the fourth meeting were $40.62 \%, 47.91 \%$, 53.12\%, and $60.41 \%$. In Cycle II, the percentage of the students' activeness from the first meeting to the fourth meeting were $69.79 \%, 75 \%, 85.41 \%$, and $88.54 \%$. Hence, the average of the students' activeness in cycle I was $50.51 \%$, and the average of the students' activeness in cycle II was $79.68 \%$. The data could be shown in the chart below:

\section{Chart Title}

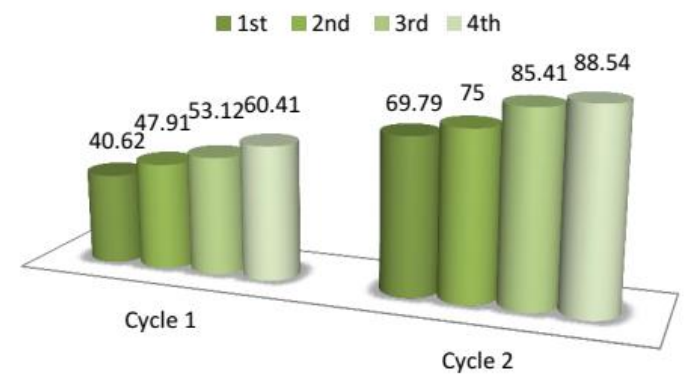

Graphic 2. The Percentage of the Students' Participation in Learning Process 
The chart above shows the students' observation in the teaching and learning writing process by using TAD Strategy. From the chart, it was known that there was a changing pattern of the students' situation in teaching and learning process from cycle I to cycle II, where in cycle I were $40.62 \%, 47.91 \%, 53.12 \%, 60.41 \%$, and the cycle II were $69.79 \%, 75 \%, 85.41 \%$, and $88.54 \%$. Hence, the average of the students' activeness in cycle I was $50.51 \%$, and the average of the students' activeness in cycle II was $79.68 \%$.

\section{CONCLUSION AND SUGGESTION}

The use of TAD Strategy could improve the students' ability in writing Recount Text viewed from its content. It can be shown from the students' mean scores of writing viewed from its content from D-Test to Cycle I until Cycle II. The students' mean scores of D-Test (60.00) $\leq$ Cycle I $(70.62) \leq$ Cycle II (77.81).

The use of TAD Strategy could improve the students' ability in writing Recount Text viewed from its organization. It can be shown from the students' mean scores of writing viewed from its organization from DTest to Cycle I until Cycle II. The students' mean scores D-Test (60.70) $\leq$ Cycle I (67.81) $\leq$ Cycle II (77.81).
The average of the students' activeness in cycle I was 50.51\%. After repairing the weakness and taking action in teaching and learning process through TAD Strategy, the average of the students' activeness becomes $79.68 \%$ in the last meeting of Cycle II. It means that the use of TAD Strategy is able to improve the students' activeness in learning English, especially in teaching Recount Text.

\section{REFERENCES}

Anderson, M., \& Anderson, K. (1997). Text type in English 2. Malaysia: MacMillan.

Byrne, F. (1986). Teaching writing skills. New York: University of Manchester.

Allen, H. B. (1972). Teaching English as a Second Language. New York: McGraw Hill.

Derewianka B. (2004). Exploring how texts work. Sydney: Primarily English Teaching Association.

Direktorat Pendidikan Menengah Umum. (1999). Penelitian pembelajaran Bahasa Inggris. Jakarta: Depdikbud.

Donahue, R. (2003). Action Research. Washington D.C: University of Pittsburgh.

Gay, L. R. (1998). Educational research: Competencies for analysis and application. Ohio: Charles E. MerrilPublishing.

Gerlach, V. (1994). Making sense of Functional Grammar. Australia: Antipodean Education Enterprise (AEE). 
Harmer, J. (2004). How to teach writing. Essex: Longman Pearson Education Limited.

Helnich, E., \& Farhady, H. (1982). Research design and statistic for Applied Linguistic. London: Newbury House Publisher, Inc.

Kusumah, W., \& Dwitagama, D. (2011). Mengenal Penelitian Tindakan Kelas. Jakarta: PT. Indeks.

Lin, B. (2006). Genre-Based teaching and Vygotskian principle in EFL: The case of university writing course. Asian EFL Journal. English Language Teaching and Research, 8(30).

Marpaung, D. (2012). Using TransitionAction-Details-Strategy writing strategy to improve writing ability. Pekanbaru: Rizky Press.

Mayers, H. M. (2002). "Something to shoot for": A Systematic Functional Approach to teaching genre in Secondary School Science. NJ: Lawrence Eribaum Associates.

Morley, D. (2007). The Cambridge introduction to creative writing. New York: Cambridge University Press.

Muhsin, M. A. (2016). Analysing the students errors in using simple present (A case study at Junior High School in Makassar). Pacific Science Review B: Humanities and Social Sciences, 2(3), 81-87.
Oshima, A., \& Hogue, A. (1997). Writing Academic English. New York: Addison Wesley Longman.

Paltridge, B. (2004). Approaches to teaching second language writing. Paper Presented at $17^{\text {th }}$ English Australia Conference, Adelaide, South Australia.

Patel, M. F., \& Jain, P. M. (2008). English Language Teaching. Jaipur: Sunrise Publisher.

Patel, M. F. (2008). Engish Language Teaching (methods, tools, and technique). Jaipur: Sunrise Publisher and Distributors.

Peha, S. (2003). Teaching that makes sense. Carrboro: Retrieved from wwW.ttms.org.

Syamsuri, A. S., Muhsin, M. A., \& Nurmayani, N. (2016). The effectiveness of caricature media in learning writing of argumentation paragraph. Theory and Practice in Language Studies, 6(11), 2079-2086.

Yakkop. (2006). Cooperative Learning in improving writing skill at SMU Nasional Makassar. A thesis (unpublished) of English Department of Unismuh Makassar. 